\title{
Sistem Informasi Persediaan Material Pendukung Produksi Pada PT. Zamrud Artistika Persada
}

\author{
Nur Laili Kholilati \\ STMIK Nusa Mandiri \\ Jakarta, Indonesia \\ lattynurlaili@gmail.com
}

\author{
Jenie Sundari \\ STMIK Nusa Mandiri \\ Jakarta, Indonesia \\ jenie.jni@nusamandiri.ac.id
}

\begin{abstract}
Sistem persediaan di PT. Zamrud Artistika Persada masih menggunakan sistem manual, transaksi permintaan material dari produksi ke gudang masih menggunakan bon nota buku pencatatan. Penanganan data dengan sistem manual ini mempunyai beberapa kendala, diantaranya menyebabkan terjadinya kesalahan dalam transaksi antara bagian produksi dengan gudang. Tujuan utama pembuatan sistem ini adalah untuk mengatasi masalah dalam pencatatan persediaan di gudang yang masih manual dan meminimalkan kesalahan dalam setiap transaksi. Untuk membantu dalam proses ini maka penulis merancang sistem yang membantu jalannya proses persediaan pencatatan barang produksi pada PT. Zamrud Artistika Persada. Sistem baru yang dirancang menggunakan bahasa pemodelan UML (Unified Modeling Language) dan perangkat pemrograman berbasis web, PHP versi 3.5.2.2 serta menggunakan basis data MySQL dengan dukungan software editor Adobe Dreamweaver versi 6.0. Sistem Ini dapat memudahkan pengguna dalam melakukan operasi persediaan barang dan produksi dan memiliki pembagian tiap user yang ada berdasarkan hak askses masing - masing, user tersebut yaitu Administrator, Admin gudang dan Admin Produksi.
\end{abstract}

Kata Kunci: Sistem Informasi, Persediaan barang, $P H P$

\section{PENDAHULUAN}

Perkembangan teknologi saat ini begitu cepat. Salah satunya adalah teknologi informasi. Dengan adanya teknologi informasi, kita tidak hanya dapat memperoleh data dan informasi dengan mudah dan cepat, namun keakuratan data juga harus diperhatikan. Persediaan barang (Inventory) atau penyimpanan barang, dalam konteks produksi adalah hal yang sangat dibutuhkan pada perusahaan yang melakukan proses produksi. Keakuratan data dan informasi barang pada proses produksi sangat penting karena akan dijadikan sebuah pelaporan informasi pembukuan.

PT. Zamrud Artistika Persada adalah perusahaan yang bergerak di bidang jasa kontraktor. Salah satu tugas pokoknya, yaitu memanajemen persediaan barang. Dalam hal ini PT. Zamrud Artistika Persada masih menggunakan sistem manual, semua transaksi persediaan barang dicatat dan kemudian dilaporkan, dengan adanya sistem semacam ini banyak permasalahan yang terjadi terutama pada sistem pelaporan yang manual seperti ini. Kendala yang di hadapi oleh PT. Zamrud Artistika Persada permintaan material barang dari gudang kecil (Produksi) ke gudang besar masih manual masih menggunakan bon nota buku pencatatan dan laporan yang semua masih di tulis tangan. Permintaan dari gudang kecil ke gudang besar masih kurang efektif di karenakan dari bagian gudang kecil tidak mengetahui apakah barang tersebut tersedia atau tidak. Untuk mendapatkan data yang di butuhkan harus mencari satu persatu nota yang telah di simpan. Sehingga tidak efektif dan efisien waktu dan pengelolaan data yang dilakukan oleh para karyawan. Maka dibutuhkan suatu wadah layanan sistem informasi persediaan barang yang dapat mempermudah manajemen perusahaan memperoleh informasi tentang laporan - laporan yang tersimpan dalam suatu database pengolahan persediaan barang mulai dari pemesanan barang sampai ke proses produksi.

\section{TINJAUAN PUSTAKA}

\section{Sistem Informasi}

a. Sistem

Menurut Dermawan, dkk (2013:4) "sistem kumpulan atau grup dari bagian atau komponen apapun baik fisik apapun baik fisik yang saling berhubungan satu sama lain dan bekerjasama secara harmonis untuk mencapai satu tujuan dan mengelolah data menjadi informasi yang berguna".

b. informasi

Menurut Dermawan, dkk (2013:2) "Informasi merupakan hasil dari pengelohan data, akan tetapi semua hasil dari pengelohan data yang tidak memberikan makna atau arti serta tidak bermanfaat bagi seseorang"'. Suatu sistem tidak akan berjalan dengan baik tanpa adanya informasi. Informasi juga disebut sebagai data yang diproses atau data yang memiliki arti. Data merupakan sumber informasi yang menggambarkan suatu kejadian yang terjadi pada saat tertentu, yang kemudian data tersebut diolah dan digunakan untuk menjadi input pada suatu sistem.

c. Sistem Informasi

Menurut Dermawan, dkk (2013:13) "Sistem Informasi merupakan kumpulan sub-subsistem yang saling berhubungan satu sama lain, yang bekerja secara harmonis untuk mencapai satu tujuan, yaitu mengelola data menjadi informasi yang berguna".

ERD 
Menurut Rosa dan Shalahuddin (2013:53) "Entity Relationship Diagram (ERD) Merupakan bentuk paling awal dalam melakukan perancangan basis data relasional. Jika menggunakan OODBMS maka perancangan ERD tidak perlu dilakukan"

\section{LRS}

Menurut Tabrani (2014:35) "LRS adalah Logical Record Structure dibentuk dengan nomor dari tipe record". Beberapa tipe record digambarkan oleh kotak empat persegi panjang dan dengan nama yang unik.

\section{UML}

Menurut Sugiarti (2013:30) "UML adalah salah satu bentuk langguage atau bahasa pencetusnya, UML di definisikan sebagai bahasa visual untuk menjelaskan memberikan spesifikasi, merancang, membuat model dan mendokumentasikan aspek-aspek dari sebuah system".

\section{METODOLOGI PENELITIAN}

Metode peneilitan yang menyangkut dalam pengumpulan data dilakukan dengan cara :

a. Studi Kepustakaan

Yaitu pengumpulan data dan informasi melalui buku-buku dan jurnal ilmiah yang sesuai dengan permasalahan yaitu Sistem Informasi Persediaan Berbasis Web.

b. Studi Lapangan

Yaitu pengumpulan data yang bersifat terjun langsung kelapangan, hal ini dilakukan untuk mendapatkan informasi yang nyata, akurat dan efisien. Adapun cara yang dilakukan dalam pengumpulan data yang dilakukan secara langsung di lapangan yaitu dengan cara :

1. Observasi

Pada metode ini pengumpulan data dan informasi dengan cara melakukan pengamatan secara langsung terhadap kegiatan yang sedang dilakukan pada PT. Zamrud Artistika Persada yang terletak di Dadap Tangerang. Dalam observasi ini perusahaan mengalami masalah dalam transaksi permintaan dan pengembalian material pendukung dari bagian produksi ke gudang.

2. Wawancara

Pada proses ini pengumpulan data melalui tatap muka dan Tanya jawab langsung kepada bagian produksi PT. Zamrud Artistika Persada yaitu kepada Bapak Irfan Daulay selaku kepala bagian produksi. Data yang diperoleh hanya sebatas permasalahan yang dialami perusahaan dalam sistem persediaan barang di bagian produksi.

\section{Model Pengembangan Sistem}

Menurut Sukamto dan Shalahuddin (2015 : 28), "Model air terjun menyediakan pendekatan alur hidup perangkat lunak secara sekuensial atau terutut dimulai dari analisis, desain, coding, testing dan maintenance." Penjelasan dari level-level yang dilalui pada model pengembangan sistem waterfall adalah sebagai berikut :

1. Analisis

Tujuan analisa kebutuhan perangkat lunak adalah untuk mengetahui ruang lingkup produk dan pemakai. Serta menganalisa hal-hal yang diperlukan dalam pelaksanaan proyek pembuatan atau pengembangan perangkat lunak(software).

2. Design

Desain perangkat lunak terdiri atas :

a. Desain struktur data

b. Desain arsitektur perangkat lunak

c. Representasi antarmuka serta desain algoritma detail

3. Coding

Proses menerjemahkan algoritma detail hasil desain ke dalam bentuk yang dapat dimengerti oleh mesin (computer).

4. Testing

Setelah dikodekan, pengujian program dilakukan. Pengujian terdiri atas dua macam tipe yaitu pengujian logika internal dan program pengujian terhadap sistem.

5. Maintenance

Proses pemeliharaan perangkat lunak dan keseluruhan dan sistem apabila terjadi kesalahan pada program atau terjadi perubahan lingkungan perangkat lunak dan juga terjadi perubahan requirement pada keadaan sebelumnya.

\section{HASIL DAN PEMBAHASAN}

\section{Proses Bisnis Sistem}

PT. Zamrud Artistika Persada merupakan salah satu perusahaan yang bergerak dibidang jasa kontraktor. Dalam proses permintaan bahan baku \& material pendukung produksi saat ini masih manual. Bagian produksi menerima berkas order produksi (pesanan produk), kemudian bagian produksi mengecek stok bahan baku \& material ada atau tidak. Jika stok tidak ada maka bagian produksi membuat form permintaan bahan baku \& material yang akan diberikan ke bagian gudang. Setelah bagian gudang menerima form permintaan barang dari bagian produksi, bagian gudang akan mempersiapkan barang yang diminta kemudian barang akan dikirimkan ke bagian produksi. Bagian produksi menerima bahan baku \& material yang diminta untuk 
selanjutnya akan di proses menjadi barang jadi, setelah barang jadi maka barang tersebut akan dikirimkan ke bagian packing. Kemudian barang yang sudah di packing akan segera di kirimkan ke customer.

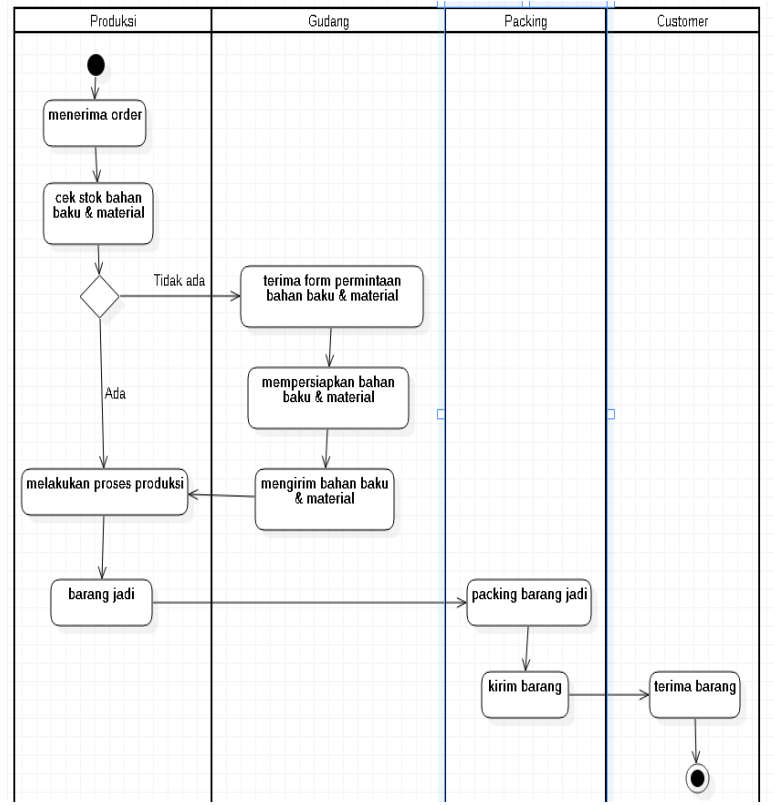

Gambar 1. Activity Diagram Persediaan material pendukung produksi pada PT. Zamrud Artistika Persada

\section{Analisis Kebutuhan Software}

Berikut ini spesifikasi kebutuhan (System requirement) dari sistem persediaan barang.

Halaman admin gudang

A.1 Admin dapat mengelola data barang

A.2 Admin dapat melakukan pemesanan barang

A.3 Admin dapat menginput penerimaan barang

A.4 Admin dapat mengelola transaksi goods transfer

A.5 Admin dapat mengelola transaksi surat jalan

A.6 Admin dapat mengelola laporan pemesanan barang

A.7 Admin dapat mengelola laporan penerimaan barang

\section{Use case Diagram}

Deskripsi Use case Diagram Halaman Admin Gudang

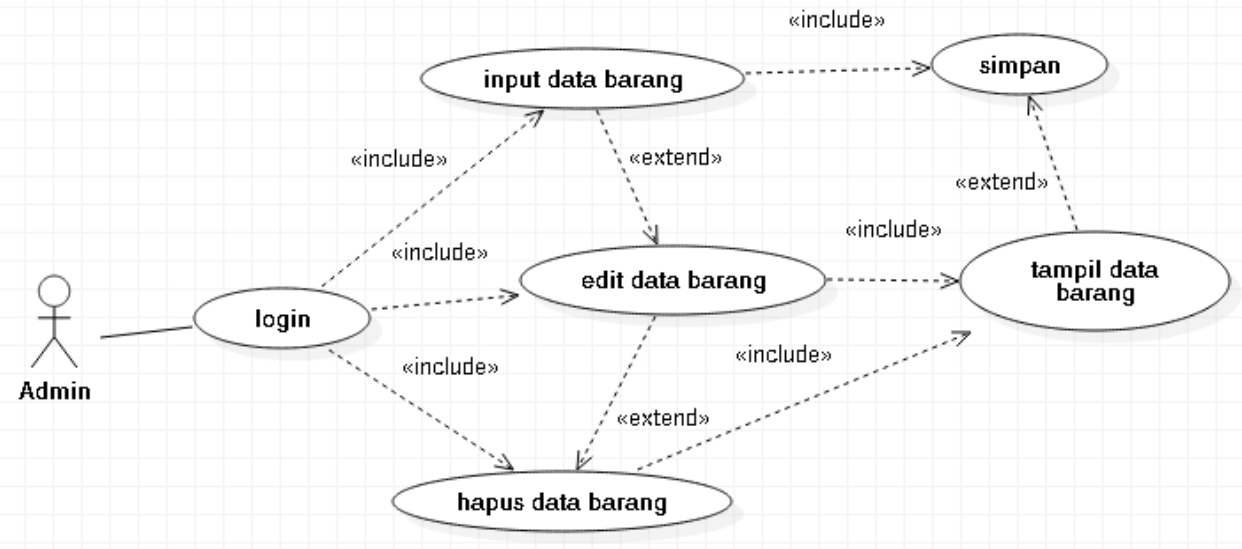

Gambar 2 Use case Diagram Admin Olah Data Barang 


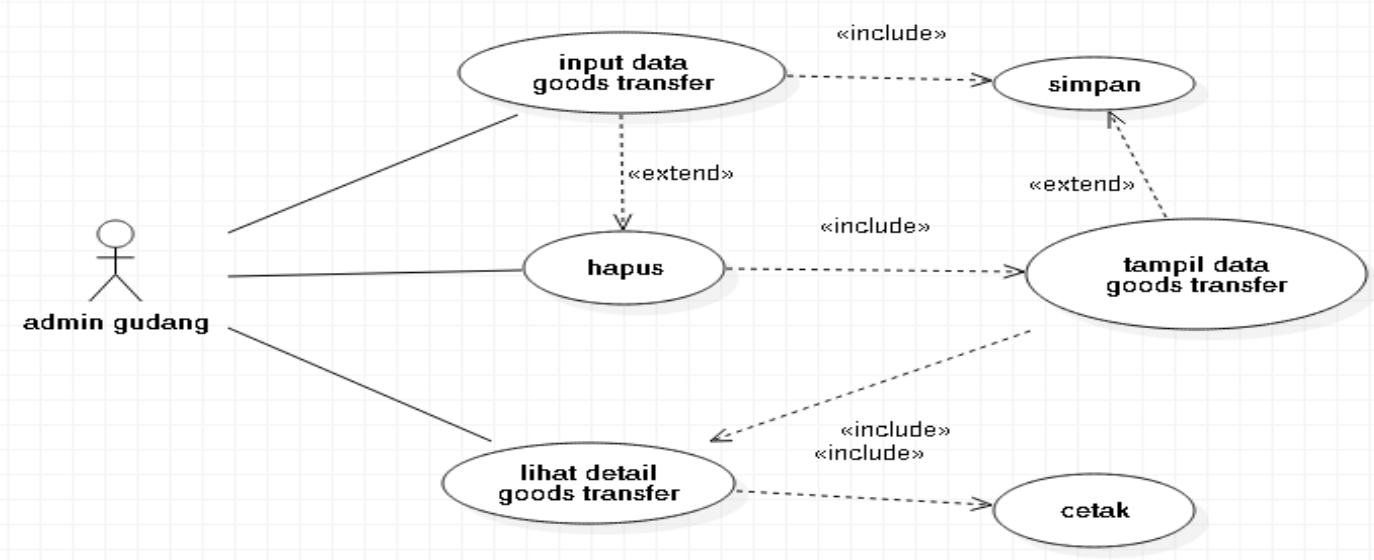

Gambar 3 Use case Diagram Admin Gudang Goods Transfer

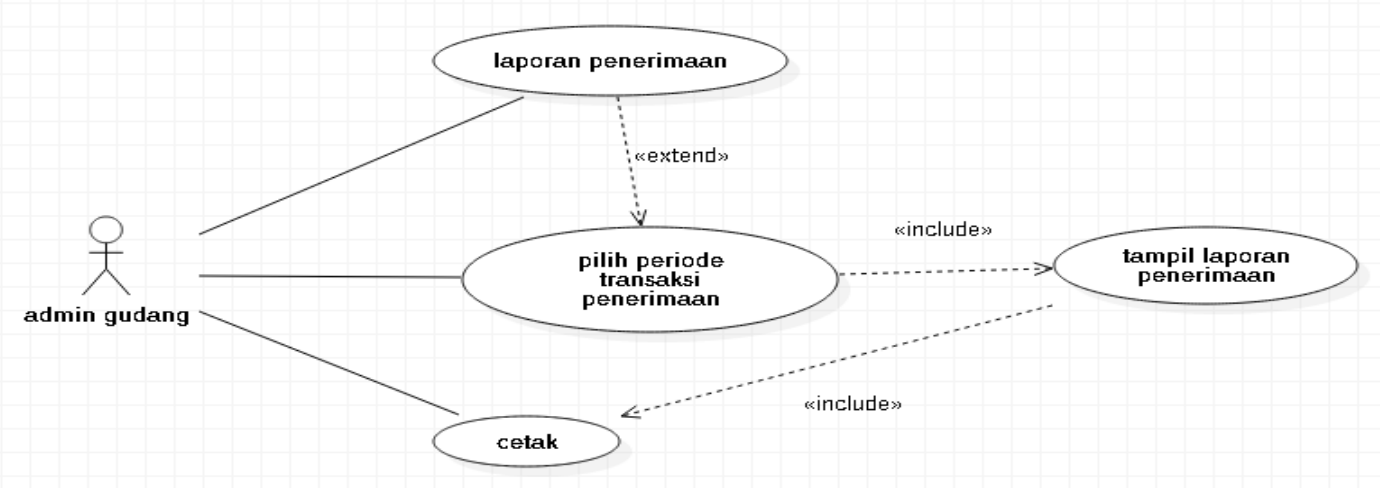

Gambar 4 Use case Diagram Admin Gudang Kelola Laporan Penerimaan Barang

\section{Activity Diagram}

Diagram aktivitas yang di gambarkan oleh penulis tidak menggunakan aktor. Berikut adalah penggambaran rangkaian aktivitas yang ada pada Sistem Informasi Persediaan Usulan.

1. Activity Diagram Login User

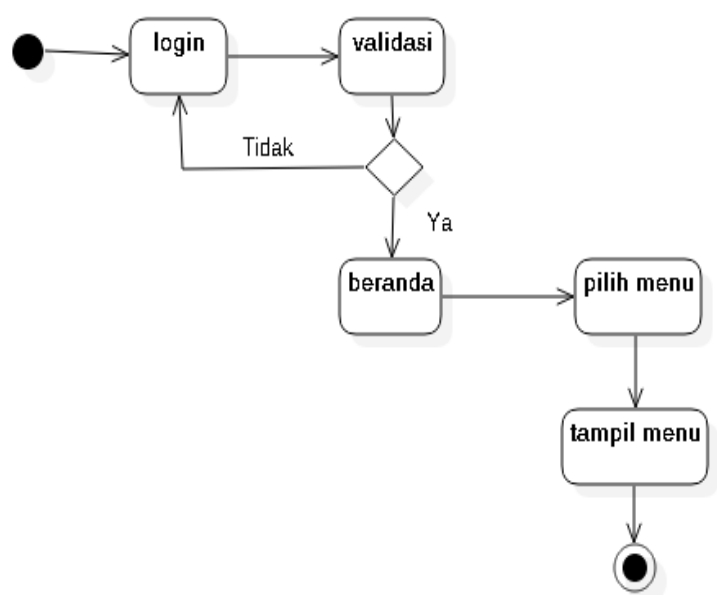

Gambar 5 Activity Diagram Login User

2. Activity Diagram Admin Olah Data Barang 


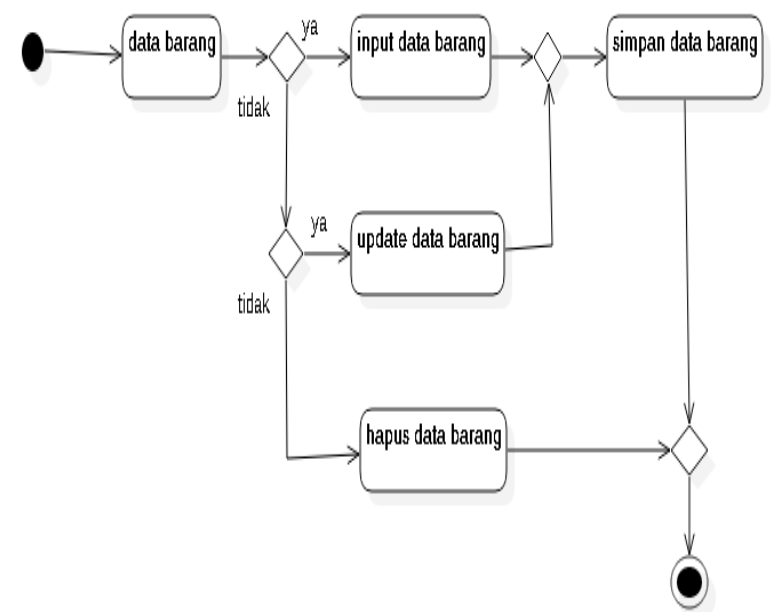

Gambar 6 Activity Diagram Admin Olah Data Barang 3. Activity Diagram Admin Transaksi Goods Transfer

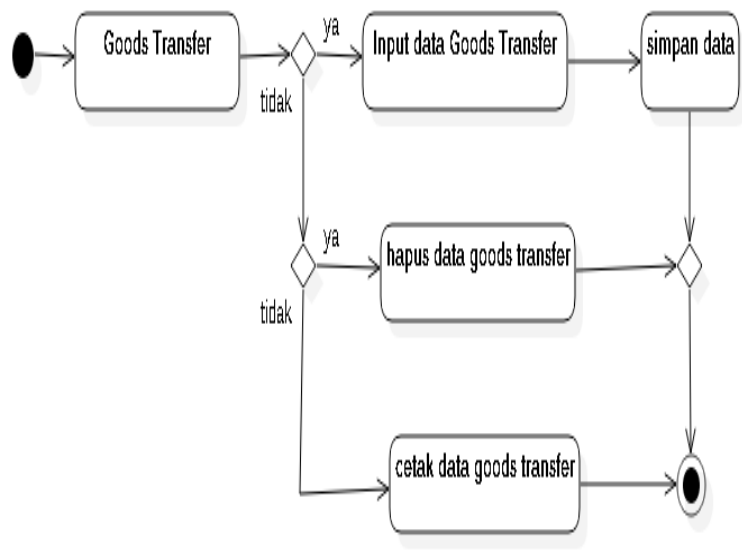

Gambar 7 Activity Diagram Admin Transaksi Goods Transfer

\section{Desain Database}

\section{Entity Relationship Diagram (ERD)}

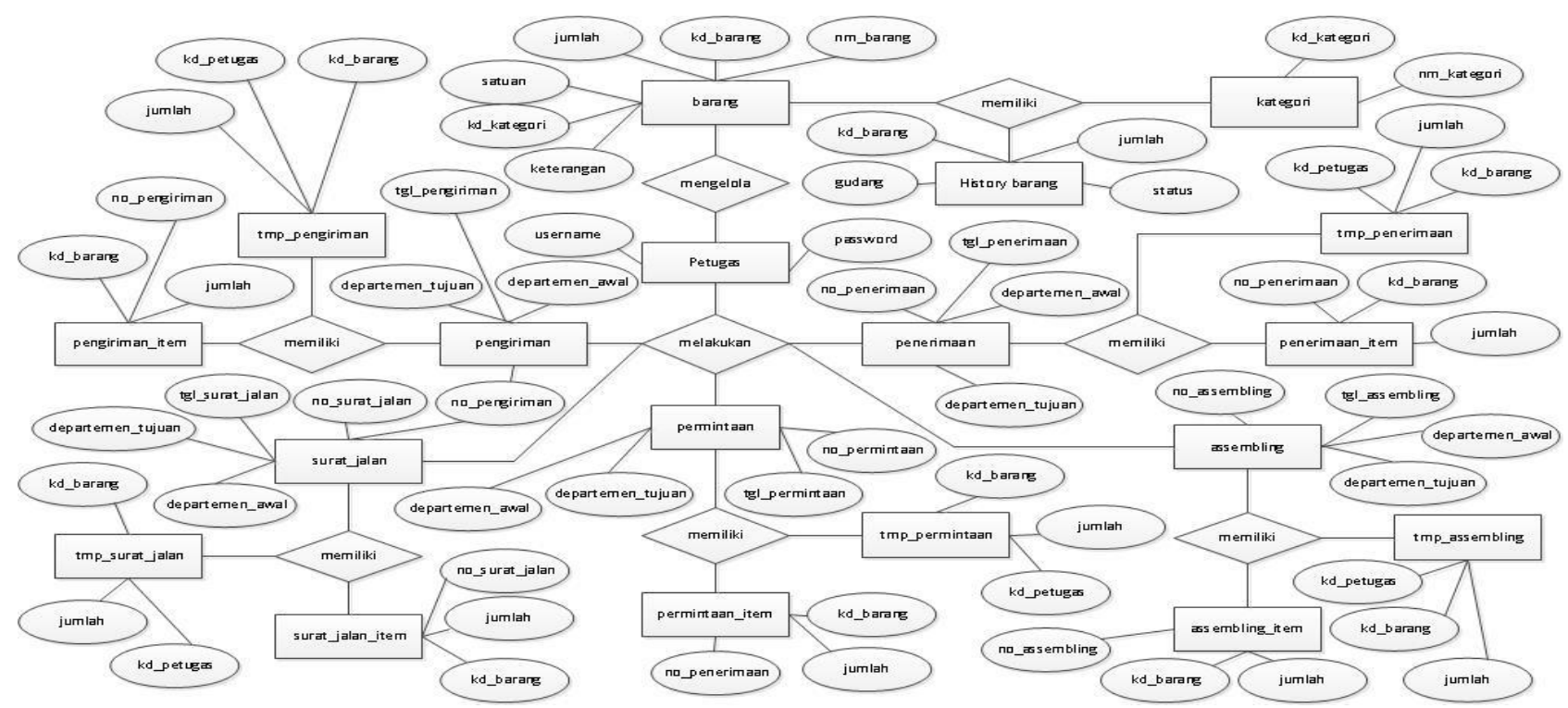


User Interface

1. Halaman Login

Gambar 8 Entity Relation Diagram Persediaan Material Pendukung Produksi

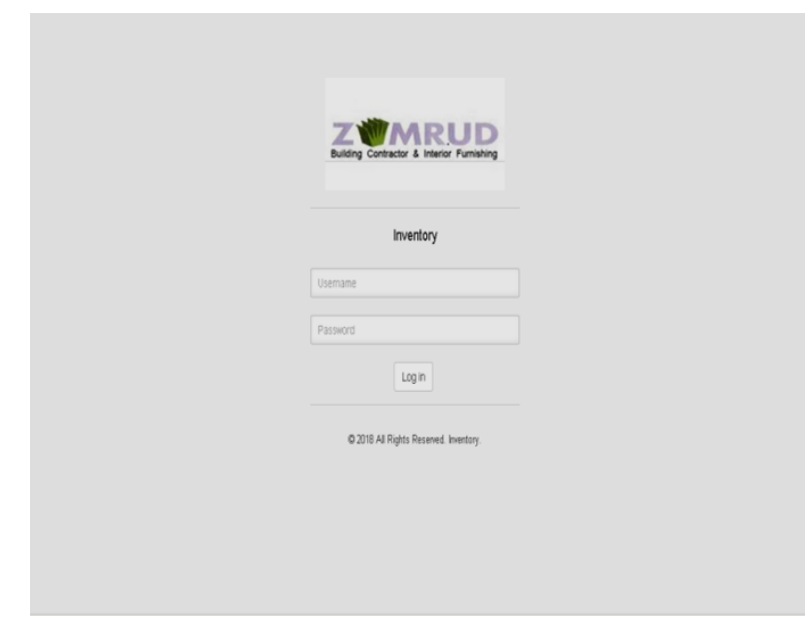

Gambar 13. Halaman Login

Sistem Informasi Persediaan Material Pendukung Produksi

\section{Halaman Beranda}

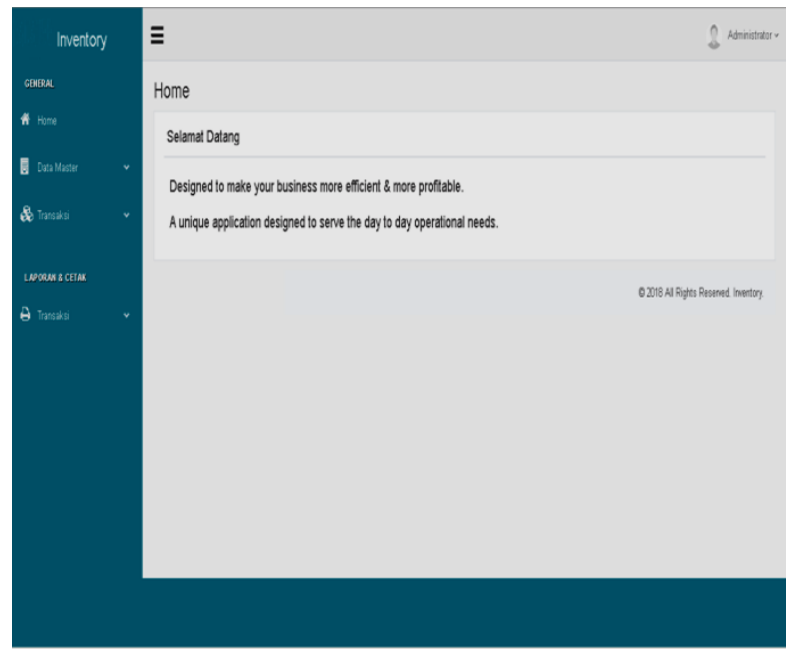

Gambar 14 Halaman Beranda

Sistem Informasi Persediaan Material Pendukung Produksi

\section{Halaman Data Barang}

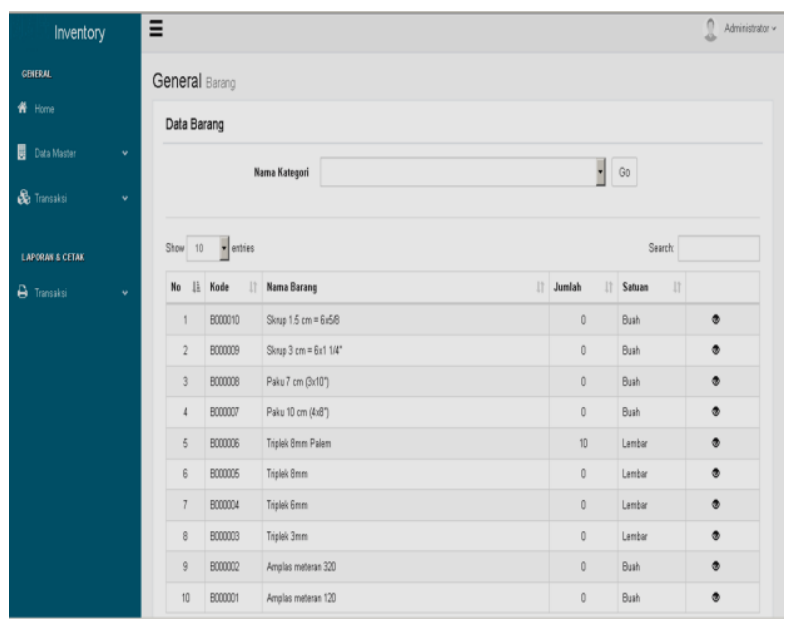


Gambar 15. Halaman Data Barang

\section{Halaman Data Goods Transfer}

\section{Sistem Informasi Persediaan Material Pendukung Produksi}

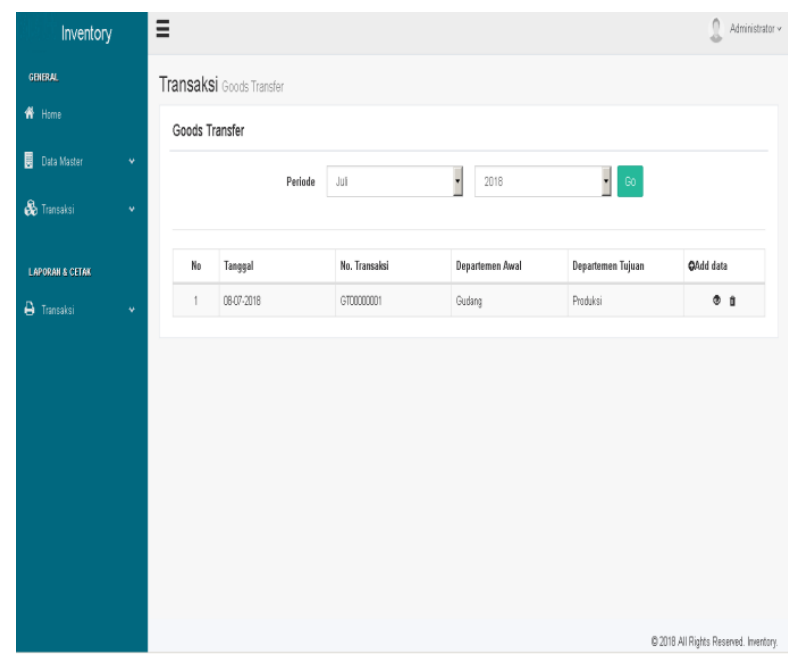

Gambar 16 Halaman Data Goods Transfer Sistem Informasi Persediaan Material Pendukung Produksi

\section{Testing}

Tabel 1

Hasil Pengujian Black Box Testing Form Login

\begin{tabular}{|l|l|l|l|l|l|}
\hline No. & $\begin{array}{l}\text { Skenario } \\
\text { Pengujian }\end{array}$ & Test Case & $\begin{array}{l}\text { Hasil yang } \\
\text { diharapkan }\end{array}$ & Hasil & $\begin{array}{l}\text { Kesim } \\
\text { pulan }\end{array}$ \\
\hline 1. & $\begin{array}{l}\text { Usemame dan } \\
\text { passwordtidak } \\
\text { disi }\end{array}$ & $\begin{array}{l}\text { Usemame:(kosong) } \\
\text { Password:(kosong) }\end{array}$ & $\begin{array}{l}\text { Sistem akanmenolakdan } \\
\text { akanmenampilkan } \\
\text { "This value is required" }\end{array}$ & Sesuai & Valid \\
\hline 2. & $\begin{array}{l}\text { Usemame disi } \\
\text { danpassword } \\
\text { tidak diisi }\end{array}$ & $\begin{array}{l}\text { Usemame:(admin) } \\
\text { Password:(kosong) }\end{array}$ & $\begin{array}{l}\text { Sistem akanmenolakdan } \\
\text { akanmenampilkan } \\
\text { "Thisvalue is required" }\end{array}$ & Sesuai & Valid \\
\hline 3. & $\begin{array}{l}\text { Usemametidak } \\
\text { disi dan } \\
\text { password diisi }\end{array}$ & $\begin{array}{l}\text { Usemame:(kosong) } \\
\text { Password:(1234) }\end{array}$ & $\begin{array}{l}\text { Sistem akanmenolakdan } \\
\text { akanmenampilkan } \\
\text { "Thisvalue is required" }\end{array}$ & Sesuaii & Valid \\
\hline 4. & $\begin{array}{l}\text { Usemame dan } \\
\text { password diisi } \\
\text { denganbenar }\end{array}$ & $\begin{array}{l}\text { Usemame:(admin) } \\
\text { Password:(1234) }\end{array}$ & $\begin{array}{l}\text { Sistem akanmenerima } \\
\text { dan akanmenampilkan } \\
\text { halaman beranda }\end{array}$ & Sesuai & Valid \\
\hline
\end{tabular}

\section{KESIMPULAN}

Berdasarkan analisis dan pembahasan pada bab sebelumnya tentang penerapan metode pencatatan dan penilaian persediaan material pendukung produksi pada PT. Zamrud Artistika Persada, maka dapat diambil kesimpulan sebagai berikut:

1. Sistem yang dibangun ini dapat mempermudah dalam proses pendataan barang masuk dan barang keluar yang sudah tersistem sehingga lebih mudah dalam pencarian data yang diperlukan.

2. Sistem ini juga dapat mempermudah bagian produksi dan gudang untuk melakukan transaksi permintaanbarang, penerimaan barang atau goods transfer.

3. Rancangan sistem informasi persediaan material pendukung produksi pada PT. Zamrud Artistika Persada bertujuan agar jumlah dan laporan akhir / awal barang dapat ditangani dengan baik dan akurat. 


\section{DAFTAR PUSTAKA}

[1] Sutabri, Tata (2012). Konsep Sistem Informasi. Yogyakarta : ANDI OFFSET

[2] Purbadian, Yendi (2015). Aplikasi Penjualan Web Base dengan PHP untuk Panduan Skripsi.Cirebon : CV. ASFA Solution.

[3] Agusvianto Hendry (2017). Sistem $\quad$ Informasi $\quad$ Inventori $\quad$ Gudang Mengontrol Persediaan Barang Pada Studi Kasus : PT.AlaisysSidoarjo. ISSN : 2549-869X IEET: Volume 01 Nomor 012017(Journal Information Engineering and Educational Technology)

[4] Rahmayu, Mulia (2015). Rancang Bangun Sistem Infomasi Nilai Ujian Siswa SMP Negeri 3 Bumiayu berbasis Web. Jurnal Khatulistiwa Informatika Vol 3 No 2 Desember 2015.

[5] Indriani, Karlena dan Sudarmadi (2015).SISTEM INFORMASI INVENTORY ALAT TULIS KANTOR (ATK) MENGGUNAKAN METODE WATERFALL (Studi Kasus : Otoritas Jasa Keuangan (OJK). Jurnal Techno Nusa MandiriVol. XII No. 1, Maret 2015

[6] Sari, Natya Permata (2015). Apa itu persediaan dalam Akuntansi?. Diambil dari www.kompasiana.com/natrya/apa-itupersediaan-dalam-akuntansi. (1 November 2017)

[7] Puspitasari, Diah (2017). Sistem Informasi Persediaan Obat Berbasis Web Pada Klinik Dan Apotek Hermantoni Karawang. Jurnal Bianglala Informatika Vol 5 No 1 - Mei 2017.

[8] A.M, Rosa dan M. Shalahuddin.(2015). Rekayasa Perangkat Lunak. Bandung : Informatika.

[9] Suciani, Ayu (2016). Pengertian Black Box Testing. Diambil dari http://timur.ilearning.me.2016/03/03/pengertian-blackbox-testing. (1 November 2017)

[10] Asari Riski Imam, Henry Bambang Setyawan, Vivine Nurcahyawati (2014). RANCANG BANGUN SISTEM INFORMASI PERSEDIAAN

BAHAN

BAKU

DENGAN

PENGENDALIAN METODE REORDER POINT.JSIKA Vol 3, No 2 (2014)/ ISSN 2338-137X JurnalSistemInformasiSitusJurnal : http://jurnal.stikom.edu/index.php/jsika

[11] Susanto Kurniawan, Erwin Gunadhi (2013). PENGENDALIAN PERSEDIAAN BAHAN BAKU LILIN DENGAN MODEL

PROBABILISTIC Q(StudiKasus Di CV. Taruna Jaya Sanding Atas - Garut).ISSN :2302-7312 Vol. 11 No. 12013 